mountains. It commenced before, but since has come down with a will. The cold too has been greater than $I$ could have conceived. In my winter clothing, and buttoned up in my overcoat, I have still been cold. This state of weather has aggravated the sickness that has attacked the whole army, measles and ty phoid. Some regiments have not over 250 for duty, some 300,500 , or about half, according to its strength. This makes a terrible hole in our effectives. Do not mention this I pray you. It will be in the papers next. The rains and constant travel have cut these dirt turnpikes so deep, the soil being rich mould in most part, that wagons can only travel with double teams. But there is a change in the weather. The glorious sun has been shining these four days. The drowned earth is reviving. The sick.improving and the spirits of all rising. Fitzhugh is very anxious to get his Buffalo robe. Did you ever get my letter concerning it? It was directed to be sent to the Spottswood to me. I asked you to put it up securely and get Col. Myers to send it to me at Huntersville. I have heard nothing of it. F. feels the want of it every night. He is very well, hearty, and sanguine. I am glad to hear of Gen. A.S. Johnston's approach, and Capt. Garnett's arrival. The disaster at Cape Hatteras was a hard blow to us, but we must expect them, struggle against them, prepare for them. We cannot be always successfui, and reverses must come. May God give us courage, endurance, and faith to strive to the end.

Good bye my dear son. F. has just come in. He sends his love and Col. W. and Capt. L. their regards. Give my kind remembrances to everybody.

Capt. G. W. Custis Lee.

Your fond father,

R. E. LeE.

\title{
SOME NOTES ON THE ENGLISH SPARROW.
}

The first is wholly in their favor. On many damp spring mornings they have been noticed busily at work on the lawn surrounding the State House at Des Moines. Pausing on these occasions to see what they were doing, one quickly perceived that they were picking up little black cutworms which seemed to be very plenty everywhere on the capitol grounds. These cut-worms were not far from three-fourths of an inch in length. A warm rain or a heavy dew brings them to the surface. It is then that scores of sparrows are so intent upon picking up and eating the pests that they scarcely notice a person who passes along the walks. Among the many things said and written about the sparrows this fact may be set. down to their credit.

The next fact to be noticed is to the credit of two certain other birds (if it be creditable to destroy these little "gamins," as the late Dr. Elliott Coues used to call them. To him the house sparrow was simply an abomination, with fow or no redeeming characteristics.) The birds which are destroying the sparrows are the screech owls (Megascops asio) and the sparrow hawks (Falco sparverius). During the autumn of 1901 two spar- 
row hawks were noticed flitting about the domes and pillars of the State House. When cold weather came they disappeared, doubtless migrating to a warmer clime. They reappeared in their old haunts about the 10 th of March following. Simultaneously with their return, the chattering of the sparrows diminished, in many places ceasing entirely, and observers were quite certain that this was due to the presence of these birds of prey, which are so keen and active on the wing.

There were many nooks and corners about the State House grounds and buildings where the sparrows were in the habit of roosting. It was noticed that they ceased to come to many of these places, and that there were indubitable signs of the presence of some larger bird which was occasionally heard during the night. On several mornings quills from the wings of sparrows were also scattered about under these perches. More than this, the sparrows wholly disappeared from more than one locality in which they had become a nuisance-a fact which has been noticed in other towns in our State. It was at once obvious to any one who studies the habits of the birds that the tragedies among the sparrows were due to the presence of screech owls which came to these localities in the night, during the autumn and winter. Evidently those who dislike the sparrows--as most persons do where these birds are too numerous-should cease to make war upon the gamy little owls and the predaceous sparrow hawk.

\section{NEW PUBLICATIONS.}

History of Iowa from the Earliest Times to the Beginning of the Twentieth Century. Four Volumes. Illustrated. By Benjamin F. Gue. Vol.I, "The Pioneer Period," pp. XXIII, 397; Vol. II, "The Civil War," pp. XVIII, 423; Vol. III, "From 1866 to 1903," pp. XII, 531; and Vol. IV, "Iowa Biography," pp. XVIII, 325. The Century History Company, New York City, 1903.

In these four handsome volumes, former Lieutenant Governor B. F. Gue has brought together the fruits of his labors for many years past in various fields of our State history. As indicated in the title, the contents of these volumes relate to, 1st, the pioneer history, $2 \mathrm{~d}$, civil war, $3 d$, our history. since the war, and finally biographical sketches of notable Iowa men. The general plan of this history includes the following distinctive features: An account of the geological or physical history of the State; a narrative of the careers of our Indian tribes; a record of the exploring expeditions in the Mississippi valley between 1673 and 1836 ; a narrative of the pioneer life and adventure and of the evolution of civil governinent from the claim club regulations to written constitutions; the formation of the early political parties and conventions; and a history of the slavery agitation. All of these features are included in the first volame. Then, follow accounts of the part taken by Iowa in the civil war, the development of our educational institutions, industries and commerce, sketches of the history of the individual counties of the State, and a 
Copyright of Annals of Iowa is the property of State of Iowa, by \& through the State Historical Society of Iowa and its content may not be copied or emailed to multiple sites or posted to a listserv without the copyright holder's express written permission. However, users may print, download, or email articles for individual use. 